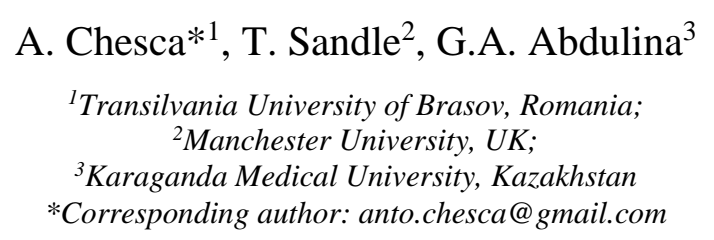

\title{
Considerations regarding liver current pathology
}

\begin{abstract}
This work presents reasoning about liver pathology. Liver pathology is an area of interest due to the growing number of medical cases worldwide. The factors associated with the appearance of this pathology are those that relate to individual lifestyle. Liver pathology studies are performed up to the biomolecular level, involving cytochrome P450 2E1 (CYP2E1). With a normal liver, subject to aging and the aforementioned risk factors, there are changes in liver structure, which often can lead to changes arising from nonalcoholic hepatic steatosis (NASH). Under certain circumstances this degenerates into chronic hepatitis, which often goes undiagnosed and this can lead to liver cirrhosis. Due to gradual changes in the liver, medical interventions are often delayed. Importantly, structural analysis of microscopically processed liver fragments will reveal changes in all structural elements of the liver, from lipid loading in hepatic steatosis to inflammatory, necrotic, destructive, fibrotic changes in liver cirrhosis, including somewhat similar changes in types of chronic hepatitis. The presented images and the described structural changes in the liver are an important criterion for liver damage, including preclinical pathology.
\end{abstract}

Keywords: liver, hepatic steatosis, chronic hepatitis, liver cirrhosis.

\section{Introduction}

Currently the microclimate and environmental factors contribute to changes in liver structure. These affect hepatocytes, which are loaded with lipid-like compounds, defining hepatic steatosis [1-3]. Under these conditions patients should adopt an appropriate lifestyle with a correct and healthy diet, avoiding stressors such as smoking and a sedentary lifestyle. Non-compliance with treatment and not following a healthy lifestyle in time can lead to conditions that further predisposes an individual to liver disease [4,5]. Under these conditions hepatocytes are affected and hepatitis B can arise, which further regresses the liver and will lead to liver cirrhosis [6]. This hepatic pathology leads to alterations of the hepatic capsule and the destruction of the hepatocytes. Moreover, modifications of the vascularization and of the other hepatic components occurs [7]. Liver pathology is often accompanied by comorbidities. These include cardiovascular disease, weight gain to obesity, and diabetes. Hence, liver pathology studies are of importance. Liver pathology studies refer to biomolecular aspects targeting cytochrome P450 2E1 (CYP2E1) [8]. Such studies show that injuries to hepatocytes, oxidative stress, aspects related to altered mitochondrial functions in the liver, energy-producing organs in the form of ATP with the production of dysmetabolic syndrome are characteristic of liver pathology $[9,10]$. This article shows these effects further. Inflammatory, necrotic, necrobiotic lesions characteristic of liver disease are also explored $[11,12]$. It is important that any observation of the structural aspects of the liver pathology is performed with sufficient lesion within the pathological anatomy service. This permits observations at the level of microscopic preparations, as illustrated in this article.

\section{Experimental}

To describe the aspects of liver pathology permanent microscopic preparations were analyzed. Comparisons were made between the structural aspects of the normal liver and the pathological aspects of hepatic steatosis and liver cirrhosis. Fragments of normal and pathological liver were taken. Permanent color microscopic preparations were made with standard staining, using Hematoxylin-Eosin, and with special staining. A Nikon microscope was used to analyze colored liver fillings. Observations were made using lenses with magnifying power of $\times 10$ and $\times 40$. The samples were taken from a population comprising of an age segment of 40-60 years, from both men and women residing in urban domicile environments. The subjects had different occupations, with different levels of education (ranging from intermediate to higher education). 


\section{Results and Discussion}

The normal liver, with its characteristic structural appearance showing binuclated hepatocytes arranged in cords, with the Disse and Kiernan space comprising the hepatic artery, the portal vein, and the bile duct, can be seen on colored preparations below, starting with the $\times 10$ magnification lens (Fig. 1).

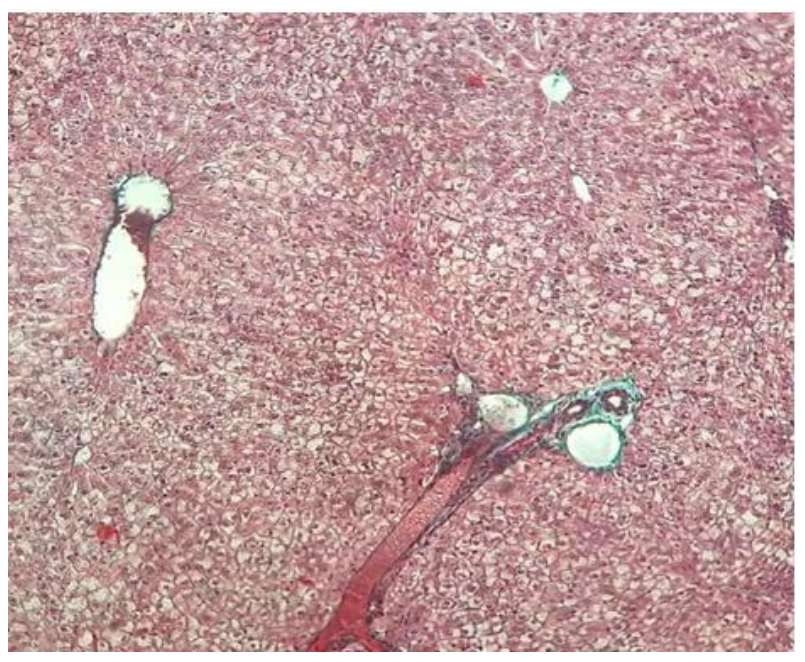

Figure 1. Normal liver. Weigert's iron hematoxylin, $\times 10$

Following the objective of the study, sections of the liver stained with Hematoxylin-Eosin and Van Gieson staining were analyzed under a microscope using $\times 10$ and $\times 40$ objectives. The lipid loading in the hepatic structure is noticeable (Fig. 2, 3).

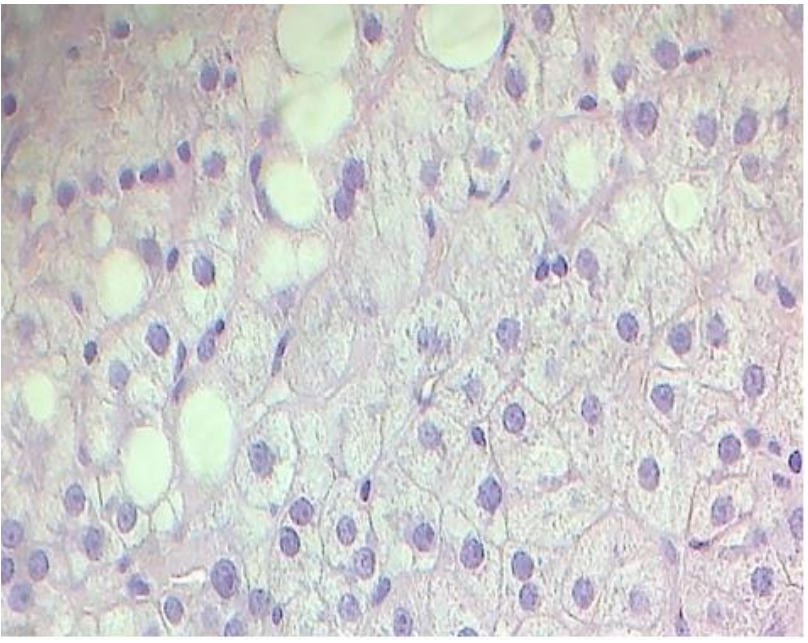

Figure 2. Liver. Hepatic steatosis. Hematoxylin-Eosin staining $\times 40$

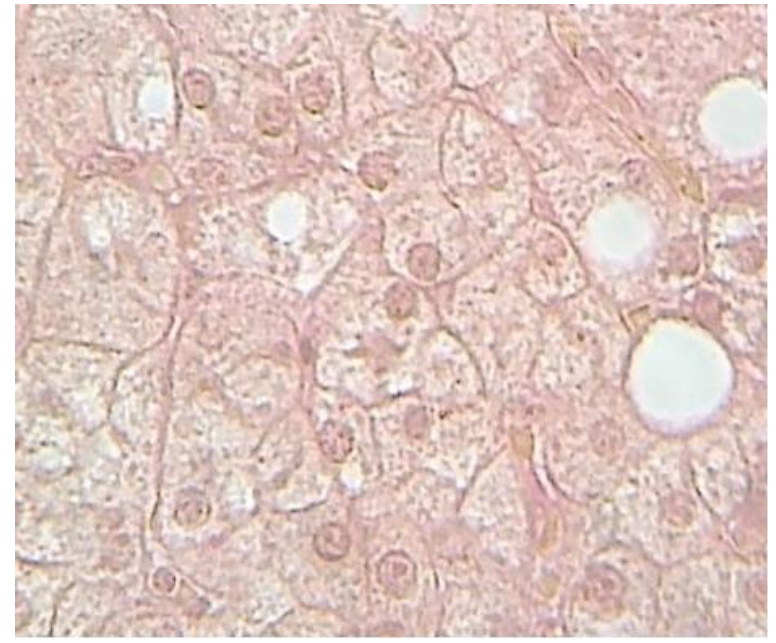

Figure 3. Liver. Hepatic steatosis.

Hematoxylin-Eosin staining $\times 40$

On the liver sections, by using an objective with increasing power $\mathrm{x} 40$, both the lipid load of the hepatocytes and their appearance can be observed, with punctiform marks of the mitochondria dispersed in the cytoplasm of the liver cells. This form of hepatocytes can be normal, but also altered. The nucleolus with nucleoli is well characterized, based on the knowledge that the hepatocyte is a binucleate cell (Fig. 2, 3).

The structural aspects of liver cirrhosis are noticeable on the microscopic preparations, both in the set of images sectioned from the diseased liver and in detail, using microscopic objectives with adequate magnifying power (respectively from $x 10$ to $\mathrm{x} 40$ ). Inflammatory and necrotic areas of hepatic steatosis are observed. There is noticeable damage to the hepatocyte cords, fibrous septa, and hepatocyte destruction (Fig. 4).

Undertaking a closer observation of the structural details, the structural aspects previously mentioned can be observed in detail (Fig. 5). 


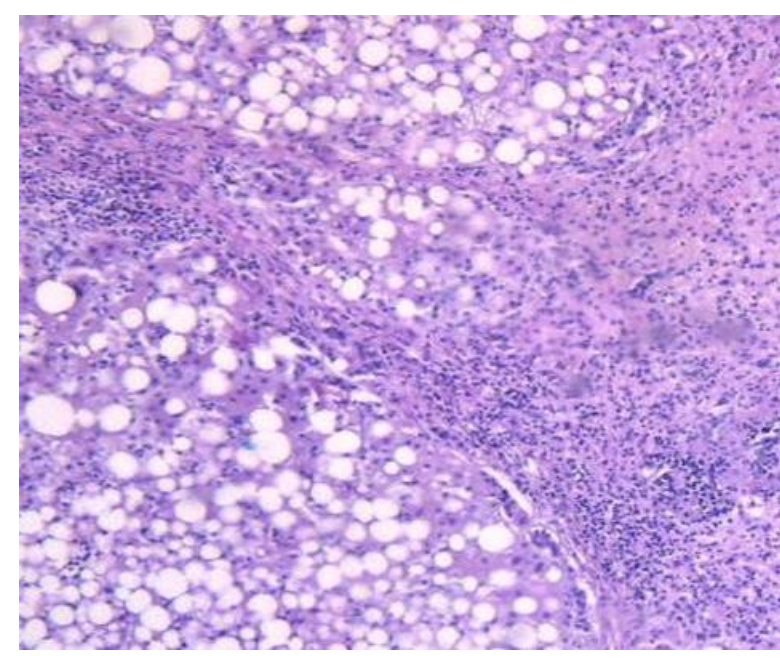

Figure 4. Liver. Hepatic cirrhosis. Hematoxylin-Eosin staining $\times 10$

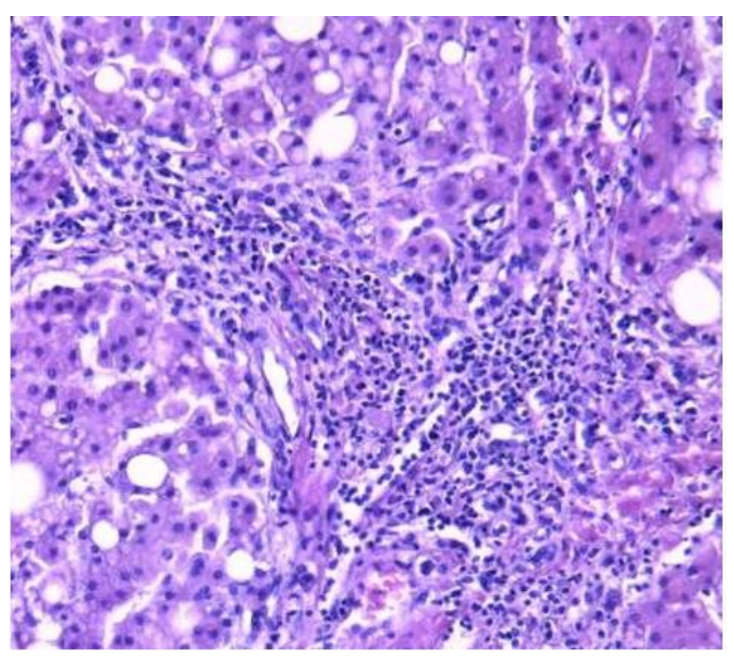

Figure 5. Liver. Hepatic cirrhosis. Hematoxylin-Eosin staining $\times 40$

With an objective with medium magnifying power the destructions of the hepatocyte cords are noticeable. In targeting the liver cells (the hepatocyte nuclei), the damage of the hepatocyte structure is clear and the lipid load has accumulated in some areas (Fig. 6).

The destructive aspects of all the structural elements of the liver are observed in liver cirrhosis using an objective with magnifying power that gives an overview of the microscopic preparations (Fig. 7).

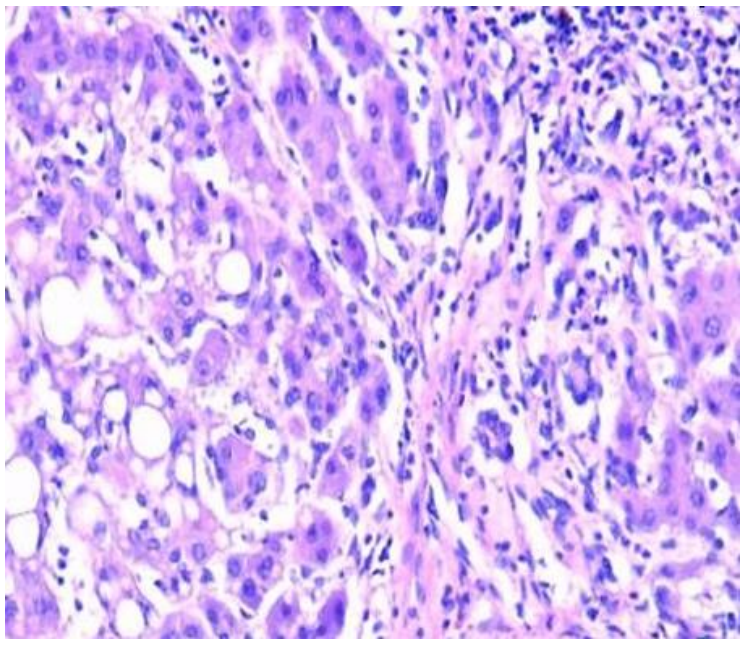

Figure 6. Liver. Hepatic cirrhosis. Hematoxylin-Eosin staining $\times 20$

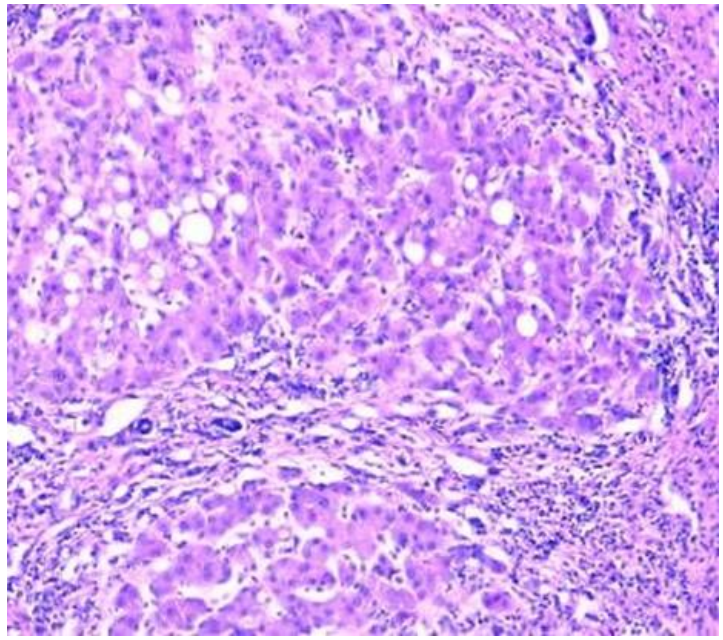

Figure 7. Liver. Hepatic cirrhosis. Hematoxylin-Eosin staining $\times 40$

The influence of an unhealthy lifestyle has detrimental consequences on an individual's health, especially in relation to the liver. Both genders are equally affected. The urban home environment is a strong pathognomonic factor for individuals. Both diet and daily stress lead to pathologies that converge, defining the patient with comorbidities. The liver is one of the organs that suffers under these conditions. The patient who does not resort, in appropriate time, to specialized medical services for diagnostic and treatment purposes, will suffer in terms of overall health. If the individual reaches specialist care in good time, a team of doctors and specialist technicians can closely monitor the patient's health and administer appropriate treatment. The clinical examination must be accompanied by a paraclinical examination for diagnostic purposes. The correct diagnosis allows the establishment of an adequate medication for curative purposes or to improve the patient's condition.

Importantly, structural analysis of microscopically processed liver fragments will reveal changes in all structural elements of the liver, from lipid loading in hepatic steatosis to inflammatory, necrotic, destructive, fibrotic changes in liver cirrhosis, including somewhat similar changes in types of chronic hepatitis. By presenting images and describing the structural changes that need to be observed, this paper presents an important aid for the medical fraternity. 


\title{
Conclusions
}

Environmental factors and the lifestyle of an individual, when not ideal for optimizing health, can significantly affect the liver. In particular, failure to follow an adequate lifestyle will lead to unfavorable pathology, leading to cirrhosis of the liver. Of greatest concern is intermediate stage hepatitis B and C. Under these poor health conditions changes in the normal structure of the liver will usually occur gradually. The gradual changes mean that sometimes medical interventions are delayed. Failure of patients to present themselves in time for an accurate diagnosis will have detrimental consequences on the timely establishment of correct and curative medication.

\section{References}

1 Schaffler A. Mechanisms of disease: adipocytokines and visceral adipose tissue-emerging role in nonalcoholic fatty liver disease / A. Schaffler, J. Scholmerich, C. Buchler // Nat. Clin. Pract. Gastroenterol Hepatol. — 2005. — Vol. 2. - P. $273-280$.

2 Adams L.A. Recent concepts in non-alcoholic fatty liver disease / L.A. Adams, P. Angulo // Diabet Med. — 2005. — Vol. 22. - P. 1129-1133.

3 Browning J.D. Molecular mediators of hepatic steatosis and liver injury / J.D. Browning, J.D. Horton // J. Clin. Invest. - 2004. - Vol. 114. - P. 147-152.

4 Mc Cullough A.J. Pathophysiology of nonalcoholic steatohepatitis / A.J. Mc Cullough // J. Clin. Gastroenterol. — 2006. Vol. 40. - P. 17- 29.

5 Weltman M.D. Hepatic cytochrome P450 2E1 is increased in patients with nonalcoholic steatohepatitis / M.D. Weltman, G.C. Farrell, P. Hall, M. Ingelman-Sundberg, C. Liddle // Hepatology. — 1998. — Vol. 27. — P. 128-133.

6 Chalasani N. Hepatic cytochrome P450 2E1 activity in nondiabetic patients with nonalcoholic steatohepatitis / N. Chalasani, J.C. Gorski, M.S. Asghar, A. Asghar, B. Foresman, S.D. Hall, D.W. Crabb // Hepatology. — 2003. — Vol. 37. — P. 544-550.

7 Schattenberg J.M. Hepatocyte CYP2E1 overexpression and steatohepatitis lead to impaired hepatic insulin signaling / J.M. Schattenberg, Y. Wang, R. Singh, R.M. Rigoli, M.J. Czaja // J. Biol. Chem. — 2005. — Vol. 280. — P. 9887-9894.

8 Comar K.M. Review article: Drug therapy for non-alcoholic fatty liver disease / K.M. Comar, R.K. Sterling // Aliment Pharmacol. Ther. - 2006. - Vol. 23. - P. 207-215.

9 Neuschwander-Tetri B.A. Nonalcoholic steatohepatitis: summary of an AASLD Single Topic Conference / B.A. Neuschwander-Tetri, S.H. Caldwell // Hepatology. — 2003. - Vol. 37. - P. 1202-1219.

10 Harrison S.A. The natural history of nonalcoholic fatty liver disease: a clinical histopathological study / S.A. Harrison, S. Torgerson, P.H. Hayashi // Am. J. Gastroenterol. — 2003. — Vol. 98. — P. 2042-2047.

11 Hui J.M. Long-term outcomes of cirrhosis in nonalcoholic steatohepatitis compared with hepatitis C / J.M. Hui, J.G. Kench, S. Chitturi, A. Sud, G.C. Farrell, K. Byth, P. Hall, M. Khan, J. George, J. // Hepatology. — 2003. — Vol. 38. — P. 420-427.

12 Adams L.A. The natural history of nonalcoholic fatty liver disease: a population-based cohort study / L.A. Adams, J.F. Lymp, J. St Sauver, S.O. Sanderson, K.D. Lindor, A. Feldstein, P. Angulo // Gastroenterology. — 2005. — Vol. 129. — P. $113-121$.

\section{А. Ческа, Т. Сандл, Г.А. Абдулина}

\section{Қазіргі уақытта бауыр патологиясына қатысты қарастырулар}

\begin{abstract}
Бауыр патологиясы бүкіләлемде медициналық жағдайлардың көбеюіне байланысты қызығушылық тудыруда. Осы патологияның пайда болуымен байланысты факторлар жеке өмір салтына қатысты болып табылады. Бауыр патологиясын зерттеу P450 2E1 (CYP2E1) цитохромының қатысуымен биомолекулалық деңгейге дейін жүргізіледі. Қартаюға ұшыраған қалыпты бауырда және жоғарыда аталған қауіп факторларында бауыр құрылымында өзгерістер байқалады, бұл көбінесе алкогольсіз бауыр стеатозынан (АБС) туындаған ауруларға әкелуі мүмкін. Белгілі бір жағдайларда бұл созылмалы гепатитке айналады, ол жиі анықталмай қалады және бұл бауыр циррозына ұшыратуы мүмкін. Бауырдың біртіндеп өзгеруіне байланысты медициналық араласулар жиі кешіктіріледі. Маңыздысы, микроскопиялық өңделген бауыр үзінділерін құрылымдық талдау бауыр статозындағы липидті жүктемеден бастап бауыр циррозындағы қабыну, некротикалық, деструктивті, фибротикалық, соның ішінде созылмалы гепатит түрлерінің біршама ұқсас өзгерістеріне дейінгі бауырдың барлық құрылымдық элементтеріндегі өзгерістерді анықтайды. Ұсынылған суреттер мен бауырдағы сипатталған құрылымдық өзгерістер бауырдың зақымдануының, оның ішінде клиникаға дейінгі патологияның маңызды критерийі болып табылады.
\end{abstract}

Кілт сөздер: бауыр, бауыр стеатозы, созылмалы гепатит, бауыр циррозы. 


\title{
А. Ческа, Т. Сандл, Г.А. Абдулина \\ Рассуждения относительно текущей патологии печени
}

\begin{abstract}
Патология печени вызывает интерес в связи с растущим числом медицинских случаев во всем мире. Факторы, связанные с появлением данной патологии, относятся к индивидуальному образу жизни. Исследования патологии печени проводятся до биомолекулярного уровня с участием цитохрома P450 2E1 (CYP2Е1). При нормальной печени, подверженной старению и упомянутым выше факторам риска, наблюдаются изменения в структуре печени, которые часто могут приводить к болезням, возникающим в результате неалкогольного стеатоза печени (НАСГ). При определенных обстоятельствах это перерастает в хронический гепатит, который часто остается невыявленным, и это может привести к циррозу печени. Из-за постепенных изменений печени зачастую медицинские вмешательства откладываются. Важно отметить, что структурный анализ микроскопически обработанных фрагментов печени способствует выявлению изменений во всех структурных элементах печени, от липидной нагрузки при стеатозе печени до воспалительных, некротических, деструктивных, фиброзных изменений при циррозе печени, включая несколько схожие изменения при типах хронического гепатита. Представленные изображения и описанные структурные изменения печени являются важным критерием поражения печени, включая и доклиническую патологию.
\end{abstract}

Ключевые слова: печень, стеатоз печени, хронический гепатит, цирроз печени.

\section{References}

1 Schaffler, A., Scholmerich, J., \& Buchler, C. (2005). Mechanisms of disease: adipocytokines and visceral adipose tissueemerging role in nonalcoholic fatty liver disease. Nat. Clin. Pract. Gastroenterol Hepatol., 2; 273-280.

2 Adams, L.A., \& Angulo, P. (2005). Recent concepts in non-alcoholic fatty liver disease. Diabet Med., 22; $1129-1133$. 152.

3 Browning, J.D., \& Horton, J.D. (2004). Molecular mediators of hepatic steatosis and liver injury. J. Clin. Invest., 114; 147-

4 McCullough, A.J. (2006). Pathophysiology of nonalcoholic steatohepatitis. J. Clin. Gastroenterol., 40; 17-29.

5 Weltman, M.D., Farrell, G.C., Hall, P., Ingelman-Sundberg, M., \& Liddle, C. (1998). Hepatic cytochrome P450 2E1 is increased in patients with nonalcoholic steatohepatitis. Hepatology, 27; 128-133.

6 Chalasani, N., Gorski, J.C., Asghar, M.S., Asghar, A., Foresman, B., Hall, S.D. \& Crabb, D.W. (2003). Hepatic cytochrome P450 2E1 activity in nondiabetic patients with nonalcoholic steatohepatitis. Hepatology, 37; 544-550.

7 Schattenberg, J.M., Wang, Y., Singh, R., Rigoli, R.M., \& Czaja, M.J. (2005). Hepatocyte CYP2E1 overexpression and steatohepatitis lead to impaired hepatic insulin signaling. J. Biol. Chem., 280; 9887-9894.

8 Comar, K.M., \& Sterling, R.K. (2006). Review article: Drug therapy for non-alcoholic fatty liver disease. Aliment Pharmacol. Ther., 23; 07-215.

9 Neuschwander-Tetri, B.A., \& Caldwell, S.H. (2003). Nonalcoholic steatohepatitis: summary of an AASLD Single Topic Conference. Hepatology, 37; 1202-1219.

10 Harrison, S.A., Torgerson, S., \& Hayashi, P.H. (2003). The natural history of nonalcoholic fatty liver disease: a clinical histopathological study. Am. J. Gastroenterol., 98; 2042-2047.

11 Hui, J.M., Kench, J.G., Chitturi, S., Sud, A., Farrell, G.C., Byth, K., \& Hall, P., et al. (2003). Long-term outcomes of cirrhosis in nonalcoholic steatohepatitis compared with hepatitis C. Hepatology, 38; 420-427.

12 Adams, L.A., Lymp, J.F., St Sauver, J., Sanderson, S.O., Lindor, K.D., Feldstein, A. \& Angulo, P. (2005). The natural history of nonalcoholic fatty liver disease: a population-based cohort study. Gastroenterology, 129; 113-121. 